\title{
In vitro Gene Delivery to HepG2 Cells with a Novel Galactosylated Polyornithine
}

\author{
Heebeom Koo, Geun-woo Jin, and Jong-Sang Park \\ School of Chemistry \& Holectlar Engineering, Seoul Kational Chiversitv, Seoul 151-747, Korea \\ "E-mail: pfjsparkíâplaza.snu.ac.kn \\ Recerved April 20, 2009, Accepted Hay 15, 2009
}

Key Words: Polyornithine. Gene delivery, Galactose. HepG2. Transfection

Various non-viral gene delivery carriers including cationic lipids. ${ }^{3}$ polypeptides. ${ }^{2}$ and polymers ${ }^{3}$ have been sỵthesized as alternatives to viral vectors. because they have many advantages such as low immune response and easy large-scale production. Among these non-viral gene carriers. using natural or artificial polypeptides such as polylysine (PLL) ${ }^{+}$polyarginine, polylistidine and polyonithine (PO) is considered as promising approach. Polylysine is one of the first gene transfer polymers to be used but polyornithine is more effective in the gene transfer into mammalian cells in vitro. ${ }^{8}$

To enhance the transfection efficiency of these carriers to a specific cell, a targeting moiety against a specific receptor in cell membrane has been bound to various gene carriers to deliver plasmid DNA by a receptor-mediated endocytosis. For instance galactose have been modified to PLL. ${ }^{9}$ chitosan. ${ }^{10}$ and $\mathrm{PEI}^{11}$ for the selective delivery of plasmid DNA to hepatocytes having specific galactose-binding receptors in their cell membrane asialoglycoprotein receptor. From this point of view. we reported how to improve the transfection efficiency

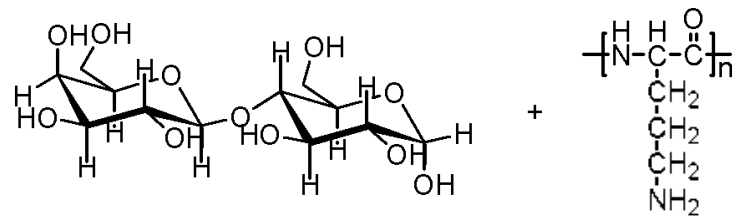

Lactose polyornithine

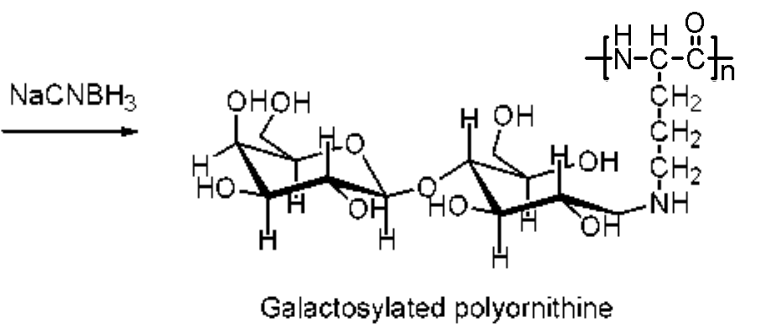

Scheme 1. Synthetic seheme of galactosylated polyonithine. of polyomithine to HepG2 cells by galactoșylation in this paper.

The galactose modification of primary amines in polyornithine is performed by reductive amination with lactose according to the literature (Scheme 1). ${ }^{12}$ The ratio between polyonithine and lactose determines the degree of galactosylation and sodium cyanoborolydride was used as the complex metal hydride in this reaction. The reaction was confirmed by ${ }^{1} \mathrm{H}-$ NMR (supporting information) and multi angle laser light scattering (MALLS) (Table 1). The increased molecular weight means successive modification of the polymers with lactose. The degree of modification was calculated from the amount of molecular weight increase in MALLS data considering the molecular weight of lactose and omithine unit. The molecular weights of polymers are between $10 \mathrm{kDa}$ and 25 $\mathrm{kDa}$. the range of the molecular weights suitable for gene delivery:

Because the electrostatic polyplex formation between cationic polymers and anionic DNA is necessary for transfection, the polyplex formation ability of polyomithine and galactosylated polyornithines were compared each other using agarose gel electrophoresis assay (Figure 1). ${ }^{13}$ The numbers in the figure represent the weight ratios between cationic polymer/ plasnuid DNA. DNA nugration disappeared when unmodified polyornithine was mixed at weight ratios of 2 and above. This disappearance means that plasnid DNA completely forms polyplex with polymer. In case of galactosylated polyornithine. the mobility of DNA with polymer was retarded at weight ratio around 3 or 4 , and it shows the complex formation abilities of galactosylated polyomithines are slightly weaker than that of initial unnodified polyomithine. It is due to the binding of lactose to primary amine groups of polyornithine and resulting decrease of amine density.

The transfection on the human hepatoblastoma HepG2 cell line was performed with the polymer-DNA complex (Figure 2). ${ }^{14}$ The transfection increase by galactosylation is remarkable in HepG2 cell line and further modification increased trans-

Table 1. The molecular weight measurement of polyomithine and galactosylated polyomithines.

\begin{tabular}{lcccc}
\hline & $M_{n}$ & $M_{w}$ & PD (M/w/Mj & Modification $(\%)$ \\
\hline Polyomithine & 14420 & 15740 & 1.092 & \\
Glactosylated polyomithine 1 & 16530 & 19220 & 1.163 & $14 \%$ \\
Glactosylated polyonithine 2 & 20050 & 22140 & 1.104 & $26 \%$ \\
\hline
\end{tabular}

Modification $\left({ }^{0} 0\right)$ means the percentage of modified anine total anine. 

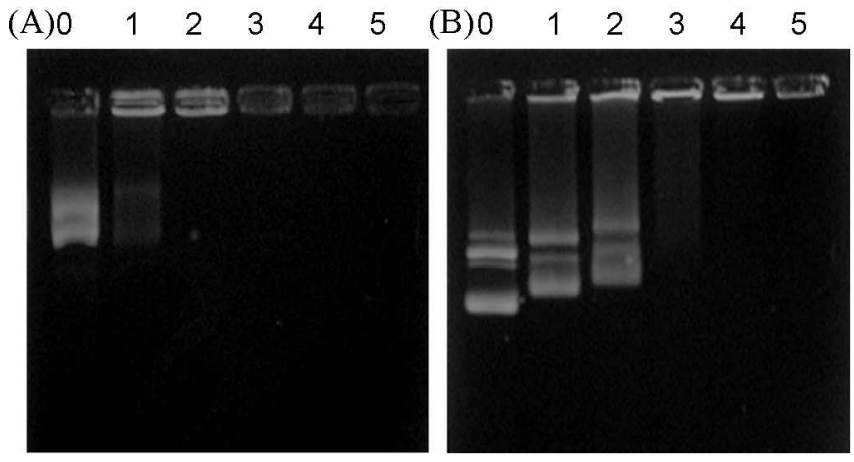

Figum 1. Agarose gel retardation assay of plasmid DNA and unmodified polyomithine $(A)$ and galactosylated polyomithine $(B)$. The number represents weight ratios (polymer/DNA)

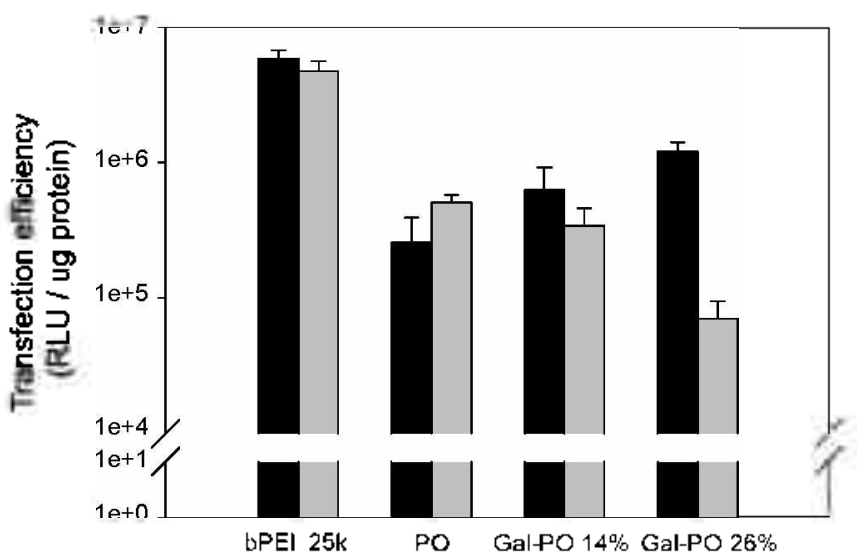

Figure 2. The comparison of the transfection efficiency on $\mathrm{Hep(i2}$ (balck bars) and NIH3T3 (gray bars) cells between branched PFI 25k, unmodified polvomithine ( $\mathrm{PO}$ ). and galactosvlated polvornithine (Gal-PO) at their optimum ratios. Branched PFI $25 \mathrm{k}$ was used as a positive control gene carrier. Jata were expressed as mean standard $(11-3)$.

fection efficiency more (black bars). Galactosy lated polyonithine $14 \%$ showed about three-fold higher transfection efficiency than unmodified polyornithine. Moreover, the transfection efficiency of galactosylated polyornithine $26 \%$ was about five times higher than that of unmodified polyornithine. It certainly showed that the more galactoses were modified, the higher transfection efficiency is achiered. Next. the change of transfection elficiency by galactosy lation was also observed in mouse enbryo fibroblast NIH3T3 cell line lacking asialoglycoproptein receptor (gray bars). The transfection efficiency of galactosy lated polyornithine was similar with unmodified polyornithine (in case of $1+\%$ ) and even decreased 10 about terth (in case of $26 \%$ ) in NIH 3T3. This opposite results supported that the increased transfection efficiency of galactosy lated polyornithine in $\mathrm{HepG} 2$ cells was becausc of receptor-1nediated pathway. In case of non-hepatoma cell lines lacking asialogly copropicin receptor. 1he large galactosyl coat would be obstacle in binding with plasmid DNA and transfection for loss of cationic charge density.

Finally. the cylotoxicitics of polyornithine poly mers were compared according to the galactosylation by MTT assay (Figure 3). ${ }^{15}$ Branched PEI 25k was used as negative control.
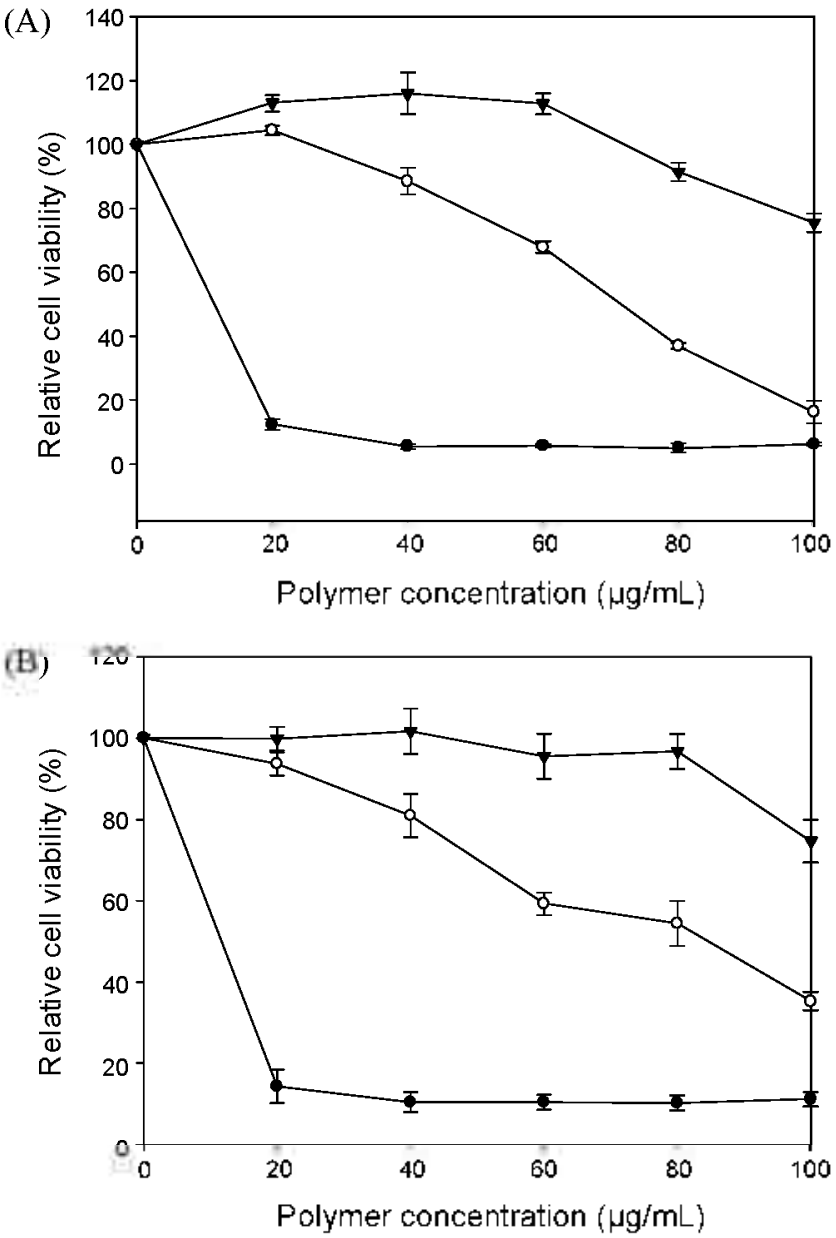

Figure 3. The crtotoxicity on $\mathrm{Het}$ ( $22(\mathrm{~A})$ and NIH3T3 (B) cells of branched PFI $25 \mathrm{kDa}($ ), polyomithine ( ), and galactosy lated polvonithine $26 \%$ ( $\mathbf{v}$ ). Branched PFI $25 \mathrm{k}$ was used as a negative conitrol. Datá were exjressed as mean standard (n = 5).

The polyornithine showed cytotoxicity at high concentration. but it is much lower than PEI 25k. The IC $\mathrm{C}_{\bar{S}}$ value of unmodified polyornithine is aboul $70 \mu \mathrm{g} / \mathrm{mL}$ in HepG2 (A) and 85 $\mu \mathrm{g} / \mathrm{mL}$ in N1H3T3 (B). But galactosylated polyomithine showed very lower cr totoxicity than unmodified. Even at $100 \mu \mathrm{g} / \mathrm{mL}$. more than $70 \%$ of cells were alive in both cell lines. This may be attributed to the masking effect of cationic charges in the poly mer against cells by large galactose. Therefore. the introduction of galactose units binded to primary amines lowered the overall cytotoxicity of polyornithine used for gene carriers.

In summary. we sunthesized galactosylated polyonilhines with various degree of modification for gene delivery systems. This galactosylated polyornithine showed slightly weaker DNA-condensing ability than unmodified polyornithine in agarose gel electrophoresis assay. Nevertheless they showed highly enlanced transfection efficiency compared to unmodified polyornithine in HepG2 cell line, while showed similar or lower efficiency in NIH3T3 cell line. This result showed the possibility of galactosylated polvornithone as a receptor mediated gene delivery carrier to specific cell. Moreover. the galactosylation of polyonithine lighly reduced its original cy totoxicity in both HepG2 and NIH3T3 cell lines. Therefore 
galactosylated polyomithine could have great potential as a non-viral gene delivery carrier into hepatoma cells with high transfection efficiency and low cytotoxicity.

\section{Experimental Section}

The Synthesis of galactosuylated polyomithine. Polyornithine $(8.018 \mathrm{mg} ; 0.5 \mu \mathrm{mol})$ and the prescribed amount of lactose were dissolved in $10 \mathrm{~mL}$ of $0.1 \mathrm{M}$ sodium tetraborate buffer at $\mathrm{pH}$ 9.0. After the addition of sodium cyanoborohydride ( 5 equiv to lactose). the mixture was reacted for 2 days at 40 ${ }^{\circ} \mathrm{C}$ with stirring. The product was purified by dialyzing against distilled. deionized water (MW cutoff, 10000) and then freezedried.

Molecular weight measurement of polymers by MALLS. Each molecular weight was determined by MALLS in combination with size-exchusion chromatography (SEC) ${ }^{16}$ The SEC system included a P680 HPLC pump from Dionex Corporation (USA). Polymer samples were detected by a threeangle laser-light-scattering detector (miniD AWN Tristar, 30 mW GaAs laser, $690 \mathrm{rum}$. K5 cell) and an interferometric refractometer (Optilab DSP. PI0 cell) from Wyatt Technologies (USA). A $1 \%$ formic acid aqueous solution was used as an eluent after filtration through a 22-nm filter and degassing. The $\mathrm{d} n / \mathrm{d} c$ value for each polymer was also measured by the same interferometric refractometer.

Transfection assay. HepG 2 and NIH3T3 cells were seeded at a density of $3 \times 10^{+}$cells/well in 24-well plates with $600 \mu \mathrm{L}$ of Dulbecco's modified Eagle's medium (DMEM) (Cambrex Bio Science, USA) containing 10\% Fatal Bovine Serum (FBS) (GIBCO. USA) and grown to $70-80 \%$ confluence for one day. Before transfection. the medium was exchanged with $480 \mu \mathrm{L}$ of FBS free DMEM. The cells in each well was treated with $120 \mu \mathrm{L}$ of PBS solution containing $1 \mu \mathrm{g}$ of $\mathrm{pCN}$-Luci plasmid DNA at various weight ratios for 4 h at $37^{\circ} \mathrm{C} .{ }^{16}$ Following 4 h-treatment of poly plexes. the medium was replaced by $600 \mu \mathrm{L}$ of fresh medium containing 10\% FBS. After an additional incubation for 2 day's. the growth medium was removed. The cells were rinsed with $240 \mu \mathrm{L}$ of phosphate buffered saline (PBS) and lysed for $30 \mathrm{~min}$ at room temperature by using 120 $\mu \mathrm{L}$ of reporter ly'sis buffer (Promega. USA). The luciferase activity was measured using a LB 9507 luminometer (Berthold, Germany). and the protein content was measured by using a Micro BCA assay reagent kit (Pierce. Rockford. IL).

Agarose gel electrophoresis. Complexes were prepared at various weight ratios between the polymer and the $\mathrm{pCN}$-Luci plasmid. The complexes were formed by incubation in HEPES buffer (25 mM HEPES . pH 7.4. $10 \mathrm{mM} \mathrm{MgCl}$ ) at room temperature for $30 \mathrm{~min}$. Each sample was then electrophoresed on a $0.7 \%(\mathrm{w} / \mathrm{v})$ agarose gel and stained in a buffer containing ethidium bromide (EtBr. $0.5 \mu \mathrm{g} / \mathrm{mL}$ ) at $37^{\circ} \mathrm{C}$ for $1 \mathrm{~h}$. The location of the DNA was analyzed on a UV illuminator.
Cytotoxicity assay. 3-[4.5-dimethylthiazol-2-yl]-2,5-dipheryl tetrazolium bromide (MTT) assay was used to measure cytotoxicity. HepG2 and NIH3T3 cells were seeded in 96-well tissue culture plates at a density of $8 \times 10^{2}$ cells $/$ well in $90 \mu \mathrm{L}$ DMEM medium containing $10 \%$ FBS. The cells achieving $70-80 \%$ confluence after $24 \mathrm{~h}$ were exposed to $10 \mu \mathrm{L}$ of various concentrations of the polymer solutions. After 2 days. $26 \mu \mathrm{L}$ of the solution of MTT (Signa, USA) ( $2 \mathrm{mg} / \mathrm{mL}$ in PBS) was added to each well. After an additional $+\mathrm{h}$-incubation at $37^{\circ} \mathrm{C}$. the media was removed and the resulting formazan was dissolved with $150 \mu \mathrm{L}$ of dimethylsulfoxide (DMSO). The absorbance was measured at $570 \mathrm{~nm}$ by using a microplate reader (Molecular Devices Company, USA). The relative cell viability was calculated as a percent absorbance to untreated control cells.

Supporting Information. NMR data is available on request to the corresponding author.

Aclonowledgments. This study was supported by a grant of the Gene Therapy Project of the Ministry of Science and Technology (Ml0534030004-08N3403-00410).

\section{Refeiences}

1. Lee, Y.: Koo, H.: Lim, Y.; Lee, Y: Mo, H.: Park, J Bioorg. Med. Chem. Letr. 2004, 14, 2637.

2. Chaloin, L.; Vidal, P.; Lory, P.; Mery, J.; Lautredou, N.; Divita, G.: Heitz, F. Biochem. Biopitw Res. Contmm. 1998, 243,601

3. Boussif, O.: Lezoualeh, F.: Zanta, M. A.; Mergny, M. D.; Scherman, D.: Demeneix, B.: and Behr, J. P. Proc. Natl Acad. Sci. $1995,92,7297$.

4. Rajur, S. B.; Roth, C. M.; Morgan, J. R.; Yamush, M. L. Bioconjugate Chem. 1997, 8,935 .

5. Männistö, M.: Vanderkerken, S.: Toncheva, V: Elomaa, M.; Ruponen, M.; Schacht. E.; Urtti, A. J Controlled Rel. 2002, 83, 169.

6. Asayama, S.; Sudo, M.; Nagaoka, S.; Kawakami, H. . fol Phamt. 2008, 5(5), 898 .

7. Mann, A.; Khan, M. A.; Shukla, V.; Ganguli, M. Biophns. Chem. 2007.129.126

8. Brown, M. D.; Gray, A. I.; Tetley, L.; Santovena, A.; Rene, T.; Schätzlein, A. G.; Uchegbu, I. F. J. Controlled Rel. $2003,93,193$.

9. Hashida, M.: Takemura, S.; Nishikawa, M.: Takakura, Y. J. Controlled Rel. 1998, 53, 301.

10. Satoh, T.; Kakimoto, S.; Kano, H.; Nakatani, M.; Shirkai, S.; Nagasaki, T. Carbohydr. Res. 2007, 342, 1427.

11. Zanta, M. A.: Boussif, O.: Adib, A.; Behr, I. P. Bioconingate Chem. 1997, 8, 839

12. Sashiwa, H.; Shigemasa, Y. Cabolndr. Polm 1999, 39, 127.

13. Yamanouchi, D.; Wu, J.; Lazar, A. N.; Kent, K. C.; Chu, C.-C.; Liu, B. Biontaterials 2008, 29,3269.

14. Lee, Y.; Cho, M. Y.; Mo, H.; Nam, K.: Koo, H.; Jin, G.; Park, J. S. Bull Kor Chem. Soc. 2008, 29,666.

15. Kim, H. . ; Kwon, M. S.; Choi, J. S.; Kim, B. H.; Yoon, .T. K.; Kim, K.; Park, J. Bull. Kon: Chem. Soc. 2007, 28, 63.

16. Lee, Y.; Mo, H.: Koo, H.: Park, T.-Y.; Cho, M. Y.: Jin, G.; Park, I.-S. Bioconingate Chem. 2007, 18, 13 . 